\title{
The Implementation of Design Based Research (DBR) in the Development of Entrepreneurial Learning for Fisherwomen in the South Coast of Malang Regency, Indonesia
}

\author{
AlfianaYuliEfiyanti ${ }^{1}$, J.G. Nirbito ${ }^{2}$, Wahjoedi ${ }^{3}$ Sunaryanto $^{4}$ \\ '(Post Graduate,Universitas Negeri Malang \& UIN Maulana Malik Ibrahim Malang, Indonesia) \\ 2, 3,4 (Universitas Negeri Malang, Indonesia)
}

\begin{abstract}
This article describes the implementation of Design Based Research in the research and development of entrepreneurial learning for fisherwomen. Poverty experienced by fishers in Indonesia became the background of this study. Central Bureau of Statistics Indonesia noted that the poverty of fishing communities is quite high,which are 7.87 million people, or $25.14 \%$ of the total of national poor population which reached 31.02 million by the year 2014. In addition, the reality of women 's role in driving the economy of fisherfamilies which is quite prominent is alsoused as aconsideration in this study. Therefore, a model of entrepreneurial learning for fisherwomen which is tested on fisherwomen in SendangBirubeach, Malang Regency is developed.

Development of the model is done by applying the Design Based Research (DBR) approach. While testing is done by using Action Research method. After going through a series of processes, research and development produce products such as lesson plan, instructional materials and instructional media. The products can be implemented on fishing communities, especially in the area of SendangBiru and on the south coast of Malang Regency, and is expected also to be applied throughout the fisherwomen in other parts of Indonesia .
\end{abstract}

Keywords:Design Based Research (DBR) approach, entrepreneurial learning, fisherwomen

\section{INTRODUCTION}

As an archipelago with approximately 17,500 islands, Indonesia has abundant marine resources. The sea area of Indonesia reaches $70 \%$ of the total area of Indonesia, as well as data from the Ministry of Marine and Fisheries in 2013, stating that the sea area of Indonesia is recorded 5.8 million $\mathrm{km}^{2}$. While the length of its coastline is $81,000 \mathrm{~km}$. Logic would say that the possession of such vast sea area will make Indonesia as a great maritime country. However, the facts show different things. Both resilience of marine and the welfare of coastal society that exist today have not been able to demonstrate the greatness of Indonesia with the potential of the sea.

Fishermen,which are the main perpetrators of fishing activities, still have not had good economic conditions. The data of BPS showed that the percentage of the poor fishers is still quite high, which reached 7.87 million or $25.14 \%$ of the total of national poor populations which reached 31.02 million people in 2014[1]. Pakpahan in Santoso (2012) stated that the poor conditions experienced by most of fishermen in Indonesia led to their low bargaining position [2].

The fishing communities in geographic terms is the people who live, grow and is developed in coastal area, which is a boundary region between land and sea. As a system, the fishing community consists of social categories that make up the social unity. They also have a system of values and symbols of culture as a reference of their everyday behavior [3].

One of the great potential of maritime in Indonesia is Malang Regency. In Malang Regency, the wealth of the south coast stretches 115 kilometers which across six districts, namely SumbermanjingWetan, Gedangan, Ampelgading, Tirtoyudo, Bantur, and Donomulyo. Coast and sea in that region do not only provide beautiful natural scenery, but also the great potential for the results of fishing. However, poverty in the fishing villages is still quite high

The important phenomenon in the lives of fishing communities is the role of the fisherwomen in driving and running the economy of their families. Fisherwomen is a term used to refer to the women who live in the fishermen environment, either as a wife, a child or a family of fishermen, or women who are not family of fishermen who work in the fishing environment. Although deep-sea fishing activities are dominated by men, fisherwomen are generally involved in activities to earn a living for their families than taking care of household chores. They usually collect shellfish, process or cookfish, clean boats which just landed, become fishmongers and open the shop, even go fix fishing equipment. However, the role of women in the fishing environment is not 
considered significant [4]. This happens because these women are not involved directly in fishing activities in the sea.

The neglect of the role of fisherwomen is not wise, given as part of the community, in the national scope; the role of all women, including fisherwomen in development is the right and obligation of women in their status or position. Women can play a role in all areas, whether in politics, economics, social, culture and development in the field of defense and security. The role can be carried out both within the family and in society. The government implemented the involvement of women in development through Presidential Decree No. 9, 2000 on gender mainstream in national development.

One effort that can be offered to optimize the role of women in fishing is to involve them intensively inmanagingthe resources so as to provide added value to such resources. Efforts to create welfare of fishing communities by giving attention to thefisherwomen have been carried out by the Food and Agriculture Organization (FAO) in India. The activity is a pilot project of the fisherwomen, by doing some multi years researchesin 1982 - 1984. FAO provides education in the form of training to thefisherwomen in India to provide the knowledge and skills to manage natural resources, as well as provide assistance to them for easier access to financial institutions. [5].

Similarly, in the south coastof Malang Regency, a form of education that can improve their knowledge and skills for fisherwomenis required, especially in the economics. Improving knowledge and skills through a learning process is expected to change people's behavior so that the fisherwomen can be triggers in improving the economic conditions of fishing communities. So it is necessary to develop a model of economic education that is focused on entrepreneurial learning. The model is arranged in accordance with the needs of the fishing communities, so that it can be effective for the community, since they are engaged in non-formal economic sector that is not tied to the official institutions.

Based on the explanation above, then a research and development by implementing the Design Based Research is conducted, which aims to develop a model of entrepreneurial learning for fisherwomen's community in the south coastofMalang Regency. It is expected that learning model can then be applied to all the fisherwomen in the district of Malang or in a larger scope, in all of fisherwomen throughout Indonesia.

\section{METHODS}

\subsection{Design-Based Research (DBR) Approach}

Baumgartner et.al. (2003), interprets the Design-based Research as a research which focuses on the designing and exploring thoroughly, so as to produce required artifacts or products. The most important point of design-based research lies in the steps of designing and testing the interventions, as well as statements made as follows:

Design-based Research methods focus on designing and exploring the whole range of designed innovations: artifacts as well as less concrete aspects such as activity structures, institutions, scaffolds, and curricula. Importantly, design-based research goes beyond merely designing and testing particular interventions.[6]

Briefly, Design Based Researchmodel which developed by Peffers et. al., (2007) (in Witjaksono, 2010) is illustrated into 6 phases as follows [7]:

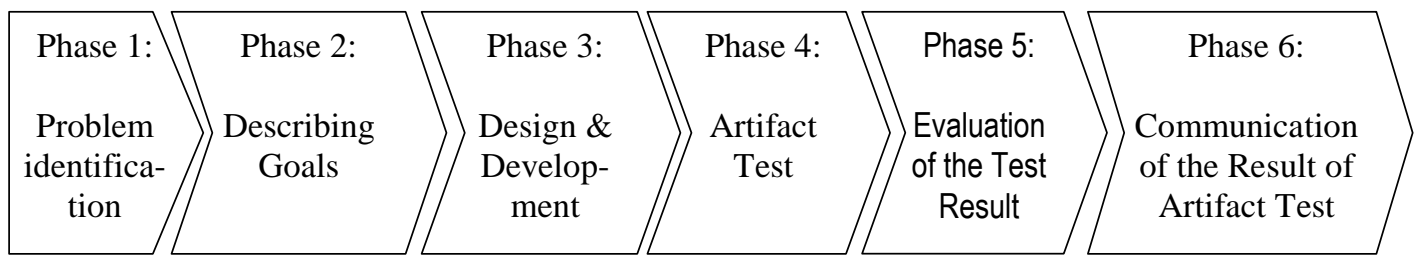

Image1. 6 phase model of Development usingDesign Based Research (DBR)

The steps of Design-based Research in its development also have undergone some evolutionary changes. Here is a scheme of evolutionary changes of Design Research Reeves model [8]:

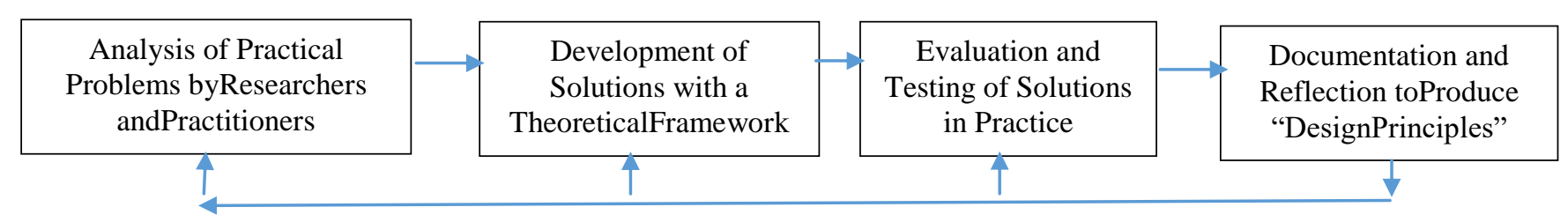


Image 2. Reeves' (2000) Development Research Model

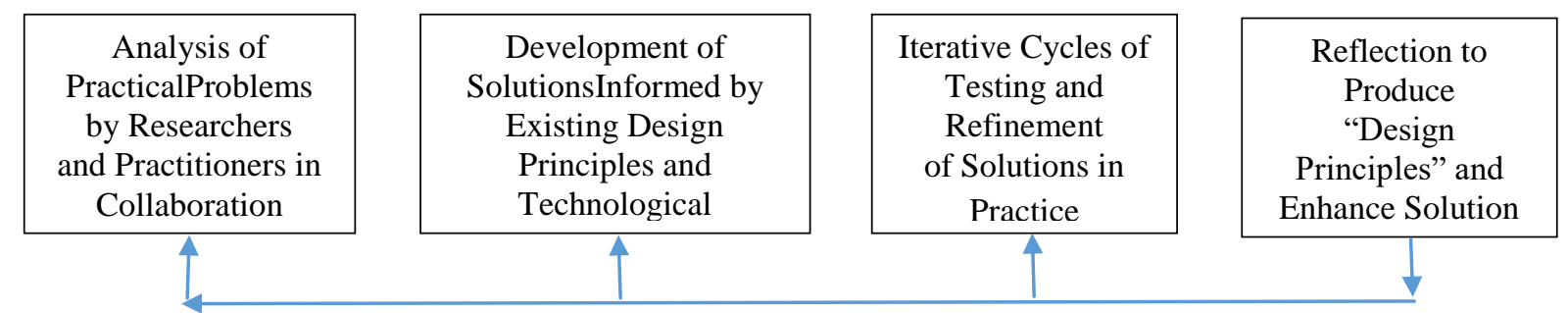

Image 3. Reeves' (2006) Design-Based Research Model

Figure 2 and Figure 3 show the evolution of the form Design-based Research Reeves model. Although both models appear similar, there is always a bit of a difference at every step, especially in the second and third step. In the second step of Revees models in 2006, including in it was appearing the principles of designing and technological innovations that directly reflect issues in the first step. The most striking change from the Reveesmodel 2000 into Reveesmodel 2006 is the repeating cycle of the testing and simplification of the solutions offered.

\section{THE IMPLEMENTATION OF DESIGN BASED RESEARCH (DBR) TO DEVELOP ENTREPRENEURIAL LEARNING MODEL FORFISHERWOMEN}

Steps of implementing Design Based Research (DBR) in developing a model of entrepreneurial learning for fisherwomencommunities are described in the schemes below:

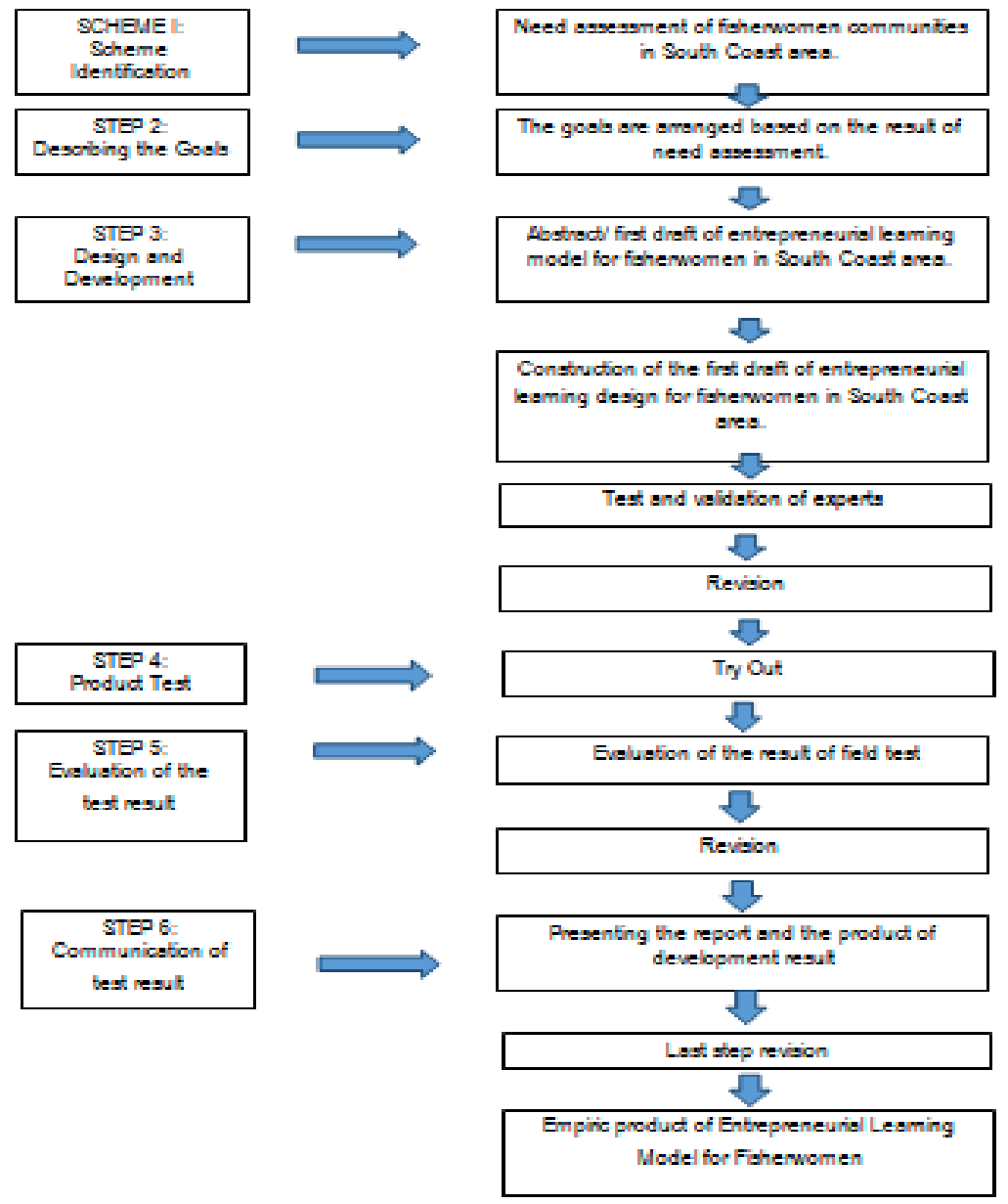

Image4.Development Model of Entrepreneurial Learning for Fisherwomen in South CoastArea in Malang Regency with the Design Based Research (DBR)approach 


\section{DEVELOPMENT RESULT}

\subsection{Development Result of Step I: Problem identification and need assessment}

The solution of problems that arise from a group can be obtained based on the input from the group itself [9]. Identification of problems and needassessment was conducted by researchers by conducting observations and interviews with fisherwomen on the Tamban and SendangBiru beach. Observations and interviews were conducted over three months, from July to September 2014. Secondary data were collected from the office of the Department of Marine and Fisheries (DKP) Malang Regency which takes a roleas builder of fisherwoman, the district office of SumberManjingWetan, headman's office and secretary of TambakRejo village.

Data which was extracted was in the form of educational background, level of knowledge and skill of entrepreneurship, entrepreneurship motivation level that are owned by fisherwomenand learning models that once they get from various parties. The educational background of fisherwomenin Southcoastal in Malang regency can be observed in Table 1 below:

Table 1The educational background of fisherwomen in south coast of Malang Regency

\begin{tabular}{|c|c|c|c|c|c|c|c|}
\hline \multicolumn{5}{|c|}{ Formal Education (\%) } & \multicolumn{2}{c|}{ Non Formal Education (\%) } \\
\hline $\begin{array}{c}\text { Not school/ not } \\
\text { graduated from } \\
\text { elementary } \\
\text { school }\end{array}$ & $\begin{array}{c}\text { Gradu } \\
\text { ated } \\
\text { fromel } \\
\text { ementa } \\
\text { ry } \\
\text { school }\end{array}$ & $\begin{array}{c}\text { Gradu } \\
\text { ated } \\
\text { fromJu } \\
\text { nior } \\
\text { High } \\
\text { School }\end{array}$ & $\begin{array}{l}\text { Gradu } \\
\text { ated } \\
\text { from } \\
\text { Senior } \\
\text { High } \\
\text { School }\end{array}$ & $\begin{array}{c}\text { Gradu } \\
\text { ated } \\
\text { from } \\
\text { S1 }\end{array}$ & Never & Training & $\begin{array}{c}\text { Other } \\
\text { education }\end{array}$ \\
\hline 0 & $15 \%$ & $51 \%$ & $33 \%$ & $1 \%$ & $88 \%$ & $12 \%$ & 0 \\
\hline
\end{tabular}

Furthermore, to determine the level of knowledge, skills and motivation for entrepreneurship, the data was collected through in-depth interviews. From interviews to the fisherwomen in Tamban and SendangBiruvillage, namely Sukanti and Imrul, data showed that fisherwomen in the south coast areas, especially in SendangBiru basically have the skills to process fish into refined products and sell the products.

However,the motivation and the effort are still weak, so they often give up when they faceobstacles. Meanwhile, to know the training models which ever received by the fisherwomen, the data was collected from the Department of Marine and Fisheries (DKP) Malang Regency, in addition to interviewing the fisherwomen. According to head of the marketing of processed fish products of DKP Malang Regency, within the last 2 years, DKP has been implementing training for fisherwomen regarding the product development. However, according to Imrul, such training is not sustainable .have a desire to be able to develop the processed products made from marine fish into various types of food products. They also hope to package the products properly in order to keep the quality and can make it more durable. Furthermore, they want the products to be able to be consumed by broader scope of consumer, outside their territories.

From the in-depth interviews, it can be concluded that the fisherwomen in the south coastof Malang Regency basically already have small businesses processing fish and they have formed a group of marine products processor, but they still face several problems, which are:

1. They do not have a good understanding of entrepreneurship.

2. They do not have a strong motivation to develop their activities into a sustainable entrepreneurial activity.

2. They have not been able to do creative and innovative products.

3. They have not been able to package the product hygienically andinterestingly.

4. They have not been able to expand the market

5 They have not been able to keep administration and financial records on their business activities.

6. They do not have the knowledge and skills to access the sources of financial/ capital.

7. They do not have knowledge and skills about the management of small businesses.

Based on the problems faced and the expectations of the fisherwomen, then to identify the needs of fisherwomen of the topics of entrepreneurial learning, the survey was conducted by distributing questionnaires, filled out by 20 fisherwomen on the SendangBiru coast,SumberManjingWetandistricts, Malang regency. SendangBiru beachwas chosen because it is a beach whichis nearest to the Fish Auctions Places (TPI) and a beach with largest fishing activity among other sub-districts in Malang regency. The results of the survey are presented in Table 2 below: 
Table 2Need Assessment ofFisherwomen to Entrepreneurial Learning Model

\begin{tabular}{|c|l|c|c|}
\hline \multirow{2}{*}{$\begin{array}{c}\text { No } \\
.\end{array}$} & \multicolumn{1}{|c|}{ Identified Components } & \multicolumn{2}{|c|}{ Attitude } \\
\cline { 3 - 4 } & \multicolumn{1}{|c|}{ Agree } & Disagree \\
\hline 1 & Need to understand the concept of entrepreneurship & $95 \%$ & $5 \%$ \\
\hline 2 & Need to understand the entrepreneurship motivation & $97 \%$ & $3 \%$ \\
\hline 3 & Need to increase the skills to develop products & $\begin{array}{r}100 \\
\%\end{array}$ & $0 \%$ \\
\hline 4 & $\begin{array}{l}\text { Need the understanding and skills to market and package the } \\
\text { product }\end{array}$ & $93 \%$ & $7 \%$ \\
\hline 5 & $\begin{array}{l}\text { Need the understanding and skills of financial records and access } \\
\text { to sources of funding }\end{array}$ & $90 \%$ & $10 \%$ \\
\hline 6 & $\begin{array}{l}\text { Need the understanding and skills to establish a business and } \\
\text { analyze business practices }\end{array}$ & $90 \%$ & $10 \%$ \\
\hline
\end{tabular}

\subsection{Development Result of Step II: Goal Formulation}

The second stage is the stage of formulatingthe learning goals for fisherwomen. Formulation of this goal is based on the identification of problems and analysis of needs (needs assessment) conducted in the first phase. With the formulation of objectives or goals, it is expected to obtain the exact model and in accordance with the conditions of the learners. The preparation of these goals was done in a Focus Group Discussion (FGD). FGD was attended by five people, who are the head of the group of fisherwomen from SendangBiru, chairman of the group of fisherwomen from Tamban, facilitators, researchers, and instructors offisherwomen from the Department of Marine and Fisheries (DKP) Malang. Fisherwomen, as learners, were involved in this FGDso that the inspiration and the needs of fisherwomen in learning will be delivered. FGDwas held on November 8, 2014.

\subsection{Development result ofStep III: Development}

The third stage is to develop the product as a form of learning models. There are 3 types of products which are developed:

\section{Learning scenarios in the form of syllabus.}

Preparation of learning scenarios in the form of a syllabus is the first step of modeling. Syllabus which is compiled refers to the grid of learning that has been set through the FGD in the previous stage. Learning scenarios which are in form of syllabus has a function as a planning and settingof learning. Syllabus includes the components of expected competencies, learning objectives, learning materials, learning strategy, learning resources and evaluation tools.

\section{Instructional material}

To facilitate the learning process, the teaching materials are developed into two, namely in the form of a facilitator guidebook and learner handbook.

Teaching materials are developed based on the lattice and syllabus which have been prepared in the previous stage. These materials contain ofentrepreneurial materials needed by the learners. To facilitate the facilitators and learners in the learning process, teaching materials compiled in this study consist of two types, namely guidebook for facilitators and learner handbook.

a. The facilitator guidebook.

This book contains of 6 materials which is divided into six sessions. At each session,learning objectives, time allocation, learning materials and evaluation are included. Session 1 contains of the material of the characteristics of entrepreneurs, session 2 contains of material of motivation in entrepreneurship, session 3 contains of materials of product development, session 4 contains of materials of product marketing, session 5 contains of material ofsimple financial records, and session 6 contains of materials of field trips. At each session, a detailed guide for the facilitators to implement the learning in the learning steps is also included.

Physically, the facilitator guide book size is standard, A4 $(21 \mathrm{~cm} \times 29.7 \mathrm{~cm})$. Cover is in the form of hard cover, in the form of union between the cover and the back. The color of cover and images illustrate the fishing activities and the results of the products produced by fishermenprocessors entrepreneurs with harmonious color degradation. The title and author's name are imprinted on the front cover with contrast colors.

The thickness of the book is 77 pages. The font used is Arial Narrow, size 12, black, and white background. To alleviate boredom, on each page there is a footer and header in dark green degraded with light green which 
contains of information of session titles, pages and types of books. The illustrationwhich is in accordance with the material is also given at each session.

\section{b. Learner Handbook}

Fisherwomen handbook contains of 6 materials, which are divided into six sessions. The substance is similarwith the facilitator guide book, but the description of the material and language is simplified in order to facilitate learners to understand it. To increase the interest in learning, pictures of illustrations that are suitablewith the subject matter are also added.

Physically, the size of the book is smaller. It isaimed to be easily carried, which is $15 \mathrm{~cm} \times 20 \mathrm{~cm}$. The cover design is also in the form of hard cover with a unity between the front and back covers, with harmonious colors. The illustration on the front cover gives an overview of the fishing activity and products produced by fishermenentrepreneurs. The title and author's name is listed with contrasting colors .

\section{Instructional Media}

Instructional media is based on the lattice of the learning model and syllabus. Instructional media is arranged to facilitate the learners to understand the material and facilitate the facilitator in the delivery of material. To make the media attractive, simple, but can carry all the materials needed, power point slides which are equipped with a short video impressions are used.

All the products which have been prepared which is a model draft, then is given input from experts, the experts do the validation process. Expert validation is done in order to obtain feedback, criticisms and suggestions as a basis for repair and improvement on an earlier draft learning model that had been developed. Test and expert validation is done by discussion and asks for feedback and advice to the three experts who each have expertise in the field of learning technologies, in the field of the training of fisherwomen and in the field of entrepreneurship content.

\subsection{Development Result StageIV: Try Out}

The model which has undergone three revisions due to the input from the three experts, thenitis piloted to the participants, or referred to as field trials. This field trial aims to determine the extent of the feasibility of entrepreneurial learning model that has been developed.

The field trial is conducted using the model by using the Bachman action research method, which is described in the following diagram [10]:

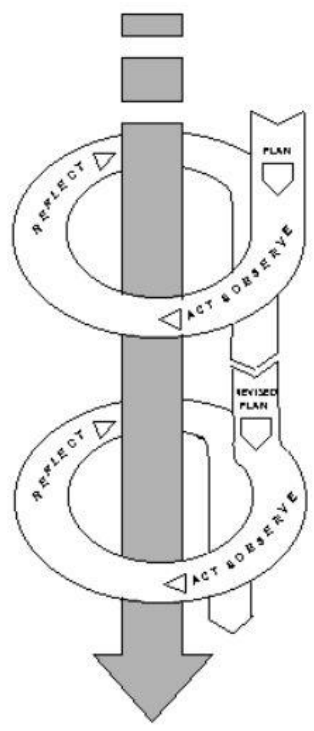

Image 5. Bachman Action Research Model

By using the model, the downward spiral states that in it, there are activities to gather information, plan of action, observe and evaluate such measures, then reflect on it, as well as design a new cycle in a view which is obtained in the previous cycle if necessary .

The responses oflearnersto the model of entrepreneurial learning are presented in Table 3 below.

Table3 
Responses of Learners to the Learning Model

\begin{tabular}{|l|l|c|c|}
\hline No & \multicolumn{1}{|c|}{ Responded Components } & \multicolumn{2}{c|}{$\begin{array}{c}\text { Percentage } \\
\text { (\%) }\end{array}$} \\
\cline { 3 - 4 } & \multicolumn{1}{|c|}{ Yes } & No \\
\hline 1 & The learning process is fun & 100 & 0 \\
\hline 2 & Learning material is understandable & 90 & 10 \\
\hline 3 & $\begin{array}{l}\text { Material of Entrepreneurs' Characteristic in session 1 is } \\
\text { understandable }\end{array}$ & 95 & 5 \\
\hline 4 & $\begin{array}{l}\text { Material of Motivationin Entrepreneur in session 2 is } \\
\text { understandable }\end{array}$ & 95 & 5 \\
\hline 5 & Material ofProduct Development in session 3 is understandable & 98 & 2 \\
\hline 6 & Material ofProduct Marketing in session 4 is understandable & 90 & 10 \\
\hline 7 & Material ofFinancial Recordin session 5 is understandable & 85 & 15 \\
\hline 8 & Material ofField Tripin session 6 is understandable & 90 & 10 \\
\hline 9 & Physical appearance of learner handbook is interesting & 97 & 3 \\
\hline 10 & Instructional media is understandable & 97 & 3 \\
\hline 11 & Time allocation is sufficient & 100 & 0 \\
\hline 12 & Exercises done is in accordance with the need of learners & 90 & 10 \\
\hline & \multicolumn{1}{|c|}{ Total } & & \\
\hline
\end{tabular}

While the attitude of learners while the learning process is presented in table 4 below.

Table 4Result of Observation to Learners While Entrepreneurial Learning Process

\begin{tabular}{|l|l|r|r|}
\hline No & \multicolumn{1}{|c|}{ Observed Components } & \multicolumn{2}{c|}{ Percentage (\%) } \\
\cline { 3 - 4 } . & \multicolumn{1}{|c|}{ Yes } & \multicolumn{1}{c|}{ No } \\
\hline 1. & Learners come on time & 100 & 0 \\
\hline 2. & Learners are asking actively if they don't understand the material. & 85 & 15 \\
\hline 3. & Learners respond the questions/ facilitators' questions. & 85 & 15 \\
\hline 4. & Learners are involved directly in the exercises and evaluation given. & 100 & 0 \\
\hline
\end{tabular}

In summary, the interview data on response, feedback and expectations of learners can be simplified as follows: 1.Learning scenario to be implemented is realistic.

2.The teaching materials, such as textbooks, require simplification of language to facilitate the understanding of learning.

3.Learning media in the form of a slide power point needs to be shortened, while the video display needs to be added.

4.Instruments evaluation to be carried out is realistic.

\subsection{Development Result Step V: Evaluation}

The fifth stage is the stage of evaluation of the feasibility model of entrepreneurial learning. The process of evaluating the feasibility of entrepreneurial learning models for fisherwomen is as follows:

1. Analyzing the learning outcome of the learners through evaluations conducted in each learning session. Based on students' learning outcomes, it can be seen that by learning model that is given, learners have additional knowledge and skills about entrepreneurship. This is proved by $80 \%$ of the learners who get good results

2. Analyzing the results of observation of the attitude of the learners

The result of observation of the attitude of the learners show that the learning model given is in accordance with the conditions of the learners, it is provedthat on average, $92.5 \%$ of learners show a positive attitude in learning. Thus the learning model is very appropriate to be applied to the fisherwomen.

3. Analyzing the response of learners to the learning model

Overall, the response of the learners to the learning model shows that the model is very feasible, with an average of $94 \%$ giving a positive response to the model.

\subsection{Development ResultStepVI: Communicating The Revision Result}

The sixth stage is communicating the product revision. This stage, according to Ellis and Levy (2010) in Sudarwati (2012) is the final stage of the overall activities, from identification of problems to test a model that is flexible and real as it is. This phase is done by communicating the results of the final revision of the model that has been done in the previous stage [11]. 
Communication of the result of revisions were made to the participants and experts, consisting of experts in the field of learning technology, experts in the field of training fisherwomen and experts in entrepreneurship. Communication is in the form of exposure of the results of product development, in the form of reports on the development and the finished product which is ready to be applied to the fisherwomen community, mainly in the south coastof Malang Regency, and coasts throughout Indonesia, which have the same characteristics as which has been revealed in this study.

\subsection{StrengthsandWeaknesses of the Model} limitations.

This entrepreneurial learning model has its strengths and of course has weakness, given the various

The strengths of the model developed are as follow:

1. The model was developed and designed on the basis of the needs of the fisherwomen, so it is relevant to be applied for them.

2. The model has been assessed and validated by three experts, who are expert in learning technology, expertinassisting fisherwomen and expert in entrepreneurship content. Based on the input and advise of the third expert, this model get some revisions.

3. The model has been tested in the field, including the group of fisherwomen inSendangBiru and Tamban From the test results, the model experienced final revision, so it's really suitable to be used in entrepreneurial learning for fisherwomen.

While weakness/ shortcoming of the model developed is that the trials were done only on entrepreneurial learning activities. Therefore, practical observation fieldcan not be done. Further development, particularly in the context of the development of fisherwomen entrepreneurs mentoring model, is required.

\section{CONCLUSION}

By using the Design Based Research approach, a model of entrepreneurial learning which is suitable for fisherwomen on the south coast of Malang Regency, Indonesia is resulted. The model is realized in the form of products, namely learning scenarios such as syllabus, teaching materials such as facilitator guidebook and participant handbook, and alsoinstructional media.

The model was tested on 20 fisherwomen on SendangBiru, Malang Regency, Indonesia. Based on the results of these trials, it can be seen that the model is effective to beimplemented. The model can then be used and further developed by the parties that concern on the education of fishing communities. The utilization is by direct use as a learning tool, sharing materials and further developmentmaterial in the field of entrepreneurial learning.

The parties which use the model of results of research and development can be in form of official institutions of government such as the Department of Marine and Fisheries, Department of Industry and Trade, the Department of Education and Culture Education Out of School, as well asnon-governmental civic institutions and Company Society Responsibility institutions,government and non-governmental companies.

\section{REFERENCES}

[1] Efiyanti, The role of fisher-women entrepreneurs to generate familly income - case in Sendang Biru coast, East Malang, Indonesia, Proc. ICEEE 1st international conferenceon Economic Education and Entrepreneurship Learning Innovations, Surabaya, Indonesia, 2016, 333-343.

[2] Imron, Masyhuri, Kemiskinan dalam masyarakat nelayan, Jurnal Masyarakat dan Budaya, 2003, Vol 5 no. 1, 63-82.

[3] Pontoh,

Otniel,IdentifikasidananalisismodalsosialdalamrangkapemberdayaanmasyarakatnelayandesaGanggaDuak abupatenMinahasautara, jurnalperikanandankelautantropis, 2010, Vol. VI-3.

[4] Nugraheni S., Peran dan potensi wanita dalam pemenuhan kebutuhan ekonomi keluarga nelayan, Journal of Educational Social Studies, 2012, 104-111.

[5] FAO Yearbook, Fishery and Aquaculture Statistics, Food and Agriculture Organisation of United Nation, Rome, 2012.

[6] Baumgartner, et. al, Design-based research: an emerging paradigm for educational inquiry, Journal of educational researcher, January 2003, vol 32, 5-8.

[7] Witjaksono, M., PeningkatanKualitas danHasilPembimbinganSkripsiMahasiswaMelaluiImplementasiPos-Skripsi, Pembangunan, FakultasEkonomi, UniversitasNegeri Malang, 2010

[8] Cotton, W., Lockyer, L. \&Brickell, G. J. A Journey Through a Design-Based Research Project, In G. Siemens \& C. Fulford (Eds.), Proceedings of World Conference on Educational Multimedia, Hypermedia and Telecommunications University of Wollongong Research Online 2009, 1364-1371. 
[9] Ellis, J. And Levy, Y., A guide for noviceresearchers: design and developmentresearchmethods, Proc, of Informing, Science \& IT Education Conference (Insite), 2010, Pp. 107-118.

[10] Mertler, Craig A., Action ResearchAlih Bahasa Daryatno, Pustaka Pelajar, Yogyakarta, 2012, 28

[11] Sudarwati, Pengembangan Model PembelajaranKewirausahaanUntukLembagaKursusRias, (Phddiss, University of Malang), 2012, 65. 